\title{
Pyelonephritis in Pregnancy: Clinical and Laboratorial Aspects and Perinatal Results
}

\section{Pielonefrite na gestação: aspectos clínicos e laboratoriais e resultados perinatais}

\author{
Djulie Anne de Lemos Zanatta ${ }^{1}$ Mariane de Mello Rossini ${ }^{2}$ Alberto Trapani Júnior ${ }^{1,2}$ \\ ${ }^{1}$ Hospital Regional Dr Homero Gomes de Miranda, São José, SC, Brazil \\ ${ }^{2}$ Hospital Universitário Polydoro Ernani de São Thiago (UFSC), \\ Florianópolis, SC, Brazil \\ Address for correspondence Alberto Trapani Júnior, MD, PhD, Rua \\ Profa. Maria Flora Pausewang, s/n, 88036-800, Trindade, \\ Florianópolis, SC, Brazil (e-mail: ginecoalberto@yahoo.com.br).
}

Rev Bras Ginecol Obstet 2017;39:653-658.

\begin{abstract}
Keywords

- pyelonephritis

- pregnancy

- pregnancy complications infectious

Objective To identify the prevalence of pyelonephritis during pregnancy and to analyze the clinical and laboratorial aspects, perinatal results and complications.

Methods A transversal study of 203 pregnant women who had pyelonephritis during pregnancy and whose labor took place between 2010 and 2016 at a hospital in the state of Santa Catarina, Brazil. The analysis was based on medical records as well as on the hospital's database. Clinical and laboratory conditions, antibiotics, bacterial resistance, perinatal outcomes and complications were all taken into account. The data was compared using the Mann-Whitney test and the Chi-square test.

Results A prevalence of $1.97 \%$ with pyelonephritis was evidenced, with most patients having it during the second trimester of gestation. The bacteria most commonly found in the urine cultures was Escherichia coli, in $76.6 \%$ of cases, followed by Klebsiella pneumoniae $(8.7 \%)$. Ceftriaxone had the lowest bacterial resistance (only $3.5 \%$ of the cases). On the other hand, ampicillin and cephalothin presented higher bacterial resistance, $52 \%$ and $36.2 \%$, respectively. The risk of very premature delivery was more than $50 \%$ higher in patients with pyelonephritis.

Conclusion Ampicillin and first-generation cephalosporins are associated with a higher bacterial resistance while ceftriaxone proved to have a high efficacy for the treatment of pyelonephritis due to low bacterial resistance. Patients with pyelonephritis showed a higher risk for very premature delivery ( $<32$ weeks). In this casuistry, there were no others significant differences in the overall perinatal outcomes when compared with the routine service series.

\section{Resumo}

Objetivo Identificar a prevalência da pielonefrite durante a gestação, analisar seus aspectos clínicos e laboratoriais, resultados perinatais e complicações.

Métodos Estudo transversal que incluiu 203 gestantes com pielonefrite durante a gestação e cujos partos aconteceram entre 2010 e 2016 em um hospital no estado de Santa Catarina, no Brasil. A análise foi feita através de informações coletadas de prontuários e da base de dados do hospital. Foram levados em consideração aspectos
\end{abstract}

received

May 17, 2017

accepted

September 9, 2017

published online

November 27, 2017
DOI https://doi.org/

10.1055/s-0037-1608627. ISSN 0100-7203.
Copyright $\odot 2017$ by Thieme Revinter

Publicações Ltda, Rio de Janeiro, Brazil
License terms

(ㄷ) (i) $\ominus$ (5) 
Palavras-chave

- Pielonefrite

- Gravidez

- Complicações infecciosas da gravidez clínicos, laboratoriais, antibioticoterapia, resistência bacteriana, resultados perinatais e complicações. Esses dados foram comparados através do teste de Mann-Whitney e do Qui-quadrado.

Resultados Foi evidenciada uma prevalência de 1,97\%, sendo que a maioria das pacientes se encontrava no segundo trimestre de gestação. A bactéria mais encontrada nas uroculturas foi a Escherichia coli, em 76,6\% dos casos, seguido pela Klebsiella pneumoniae $(8,7 \%)$. A ceftriaxona, usada como primeira escolha, demonstrou ser o antibiótico com menor resistência bacteriana (apenas 3,5\% dos casos). A ampicilina e a cefalotina apresentaram maiores resistências bacterianas, $52 \%$ e $36,2 \%$, respectivamente. O risco de parto prematuro extremo ( $<32$ semanas) foi mais que $50 \%$ maior em pacientes com pielonefrite.

Conclusão A ampicilina e cefalosporinas de primeira geração estão associadas à maior resistência bacteriana enquanto a ceftriaxona provou ter uma alta eficácia para o tratamento da pielonefrite devido à baixa resistência bacteriana. Pacientes com pielonefrite têm maior risco para parto prematuro extremo ( $<32$ semanas). Nesta casuística, não houveram outras diferenças significativas nos resultados perinatais gerais quando comparados com a série de serviços de rotina.

\section{Introduction}

Urinary tract infections (UTIs) have great relevance in the gestational period, specially pyelonephritis, which is one of the most common causes of hospitalization during the prenatal period. ${ }^{1}$ Despite the decrease in the incidences of pyelonephritis in recent years due to improved follow-up during prenatal care, the development of a resistance to antibiotics and other factors may influence its diagnosis and treatment. ${ }^{2}$

Asymptomatic bacteriuria (ASB), defined by a urine culture collection that presents $>100,000$ colony forming units (CFU) of a single pathogen, substantially increases the risk of pyelonephritis during pregnancy. The treatment of ASB reduces the chance of pyelonephritis from $20-35 \%$ to $1-4 \%$, and it also prevents low birth weight and intrauterine growth restriction. ${ }^{3,4}$

There is a predisposition to pyelonephritis in the gestational period and it is mainly due to physiological changes that occur during gestation. From the 12th week of gestation, it is possible to observe ureteral dilatation as well as renal calices due to the progesterone-induced relaxation. Therefore, there is a decrease in ureteral peristalsis, which together with ureteral enlargement and ureteral compression, especially on the right side, as well as compression of the bladder, with consequent loss of emptying capacity, associated with increased urine output, may contribute to urine stasis. ${ }^{5,6}$

The clinical findings of pyelonephritis are: fever with abrupt onset, acute pain that may be exacerbated by the maneuver of the cuff-percussion at costovertebral angles, nausea and vomiting. ${ }^{7}$ Identification of the pathogen for diagnosis and treatment planning is done by urine culture.

The most common uropathogen in urine samples is Escherichia coli, present in $\sim 95 \%$ of the cases of pyelonephritis in pregnant women. ${ }^{8}$ Other microorganisms can also be found on a smaller scale such as: Klebsiella pneumoniae, Enterobacter aerogenes, Proteus mirabilis, Enterococcus faecalis and group B Streptococcus. ${ }^{9}$
Most pregnant women diagnosed with pyelonephritis should be initially hospitalized for empirical treatment until the result of the uroculture for pathogen identification and the antibiotic sensitivity test (AST). According to Artero et $\mathrm{al}^{10}{ }^{10}$ Amoxicillin-Clavulanate and Cephalosporin have shown to be adequate choices for empirical treatment. In untreated cases of pyelonephritis, there is an increased risk of fetal and maternal morbidity such as fever, renal failure, preterm birth and stillbirth. ${ }^{11}$ Additionally, sepsis can be one the most feared complications among pregnant patients, increasing the risk of acute respiratory distress syndrome and a higher risk of emergent cesarean delivery. ${ }^{12}$

Taking into account these considerations, this study aims to evaluate clinical and laboratory findings, as well as perinatal complications associated with pregnant women diagnosed with pyelonephritis, to contribute to the understanding of the risks associated with the disease and to provide clarification for public health purposes.

\section{Methods}

An observational and cross-sectional study was conducted at a maternity of a public university hospital in Florianópolis, Brazil.

The collection was performed via an electronic database containing information on the medical records of all pregnant women attended between January of 2010 and December of 2016 who had the diagnosis of pyelonephritis. During this period, there were 10,291 births of single fetuses and 203 pregnant women diagnosed with pyelonephritis. All cases of twinning, abortion (birth weight less than $500 \mathrm{~g}$ or gestational age $[\mathrm{GA}] \leq 20-22$ weeks) and 11 cases in which hospitalization due to pyelonephritis occurred at another hospital were excluded.

The diagnose of pyelonephritis was defined by the presence of a positive urine culture ( $>100.000 \mathrm{CFU}$ of organisms) 
as well as at least one of the clinical findings: fever $\left(>37.8^{\circ} \mathrm{C}\right)$, costovertebral angle pain and flank pain.

Demographic and clinical data from patients who had the diagnose of pyelonephritis during the gestational period were obtained through hospital electronic records followed by charts review. The search was guided by a pre-established study protocol. The following variables and outcomes were evaluated: leukocyturia ( $>10.000$ white blood cells $/ \mathrm{ml}$ ), anemia (hemoglobin $<11$ ), need for intensive care unit (ICU), diabetes, systemic arterial hypertension (blood pressure over $130 / 85 \mathrm{mmHg}$ ), human immunodeficiency virus (HIV), use of illicit drugs, length of hospital stay, days of treatment, antibiotic in use and antibiogram.

Data from 6,010 births within the same period were used for comparison of perinatal outcomes in women with no history of pyelonephritis or diseases prior to pregnancy (58.4\% of all single births). The following variables were analyzed: APGAR score, weight at birth, postpartum hemorrhage, preeclampsia and cesarean section and GA at birth, which was divided in premature delivery (GA $<37$ weeks) and very premature delivery (GA $<32$ weeks)

All the variables in the research were analyzed through the software SPSS 16.0 (SPSS Inc., Chicago, IL, USA), the quantitative variables were compared through the Mann-Whitney test and the qualitative variables through the Chi-square. Values of $p<0.05$ were considered statistically significant.

The research was approved by the Human Research Ethics Committee (HREC) in Brazil, under the protocol number 461.143.

During this research, there were no conflicts of interest identified by the authors.

\section{Results}

Total 10,291 single-fetal births were recorded between January of 2010 and December of 2016. Two-hundred and three of the pregnant patients were diagnosed with pyelonephritis at some time during pregnancy, resulting in a prevalence of $1.97 \%$.

Most of the pregnant women diagnosed with pyelonephritis were in the second trimester of gestation (54.6\%). Only $10.9 \%$ of the pregnant women were in the first trimester of pregnancy at the time of diagnosis. The mean GA was 24.1 weeks with a standard deviation (SD) of 4.7 at the time the infection was diagnosed.

The most common clinical and laboratory findings were: leukocyturia (94.7\%), fever $(80.2 \%$ ) and pain in the costovertebral angle (72.3). Anemia was evident in $21.8 \%$ of the patients (-Table $\mathbf{1}$ ).

Regarding prenatal care, it was observed that of the 192 pregnant women hospitalized for pyelonephritis, 161 (83.9\%) were already under regular follow-up.

Most patients remained hospitalized for less than 7 days (91\%) and required less than 7 days of intravenous antibiotic therapy (92.1\%). More than half of the patients in intravenous treatment (46.3\%) did not require hospitalization for longer than 3 days. Patients who had extended hospital stay, for a period longer than 7 days, were the most severe cases, in which the majority required intensive care unit (ICU) hospitalization.
Table 1 Breakdown of pregnant women who had pyelonephritis during pregnancy attended at the UH / UFSC, during the years 2010 to 2016, according to clinical and laboratory characteristics $(n=192)$

\begin{tabular}{|l|l|}
\hline Characteristics & $\mathbf{n}(\%)$ \\
\hline Leukocyturia & $182(94.7)$ \\
\hline Fever & $154(80.2)$ \\
\hline Costovertebral angle pain & $139(72.3)$ \\
\hline Flank pain & $129(67.1)$ \\
\hline Anemia $(\mathrm{Hb}<11 \mathrm{~g} / \mathrm{dL})$ & $42(21.8)$ \\
\hline Need for ICU & $14(7.2)$ \\
\hline Diabetes Mellitus & $7(3.6)$ \\
\hline SAH & $5(2.6)$ \\
\hline HIV positive & $6(3.1)$ \\
\hline Use of illicit drugs & $7(3.6)$ \\
\hline
\end{tabular}

Abbreviations: $\mathrm{Hb}$, hemoglobin; HIV, human immunodeficiency vírus; ICU, intensive care unit; SAH, systemic arterial hypertension

Among the 192 cases analyzed, it was not possible to identify the bacteria in the urine culture of 21 of them $(10.9 \%)$. It is verified that the bacteria of highest incidence in the urine culture corresponds to Escherichia coli, isolated in $76.6 \%$ of the antibiograms in which the agents were identified, followed by Klebsiella pneumoniae (8.7\%) and Proteus mirabilis (4\%), as demonstrated in - Table 2.

The most commonly used antibiotic for the intravenous phase was ceftriaxone, used in 197 patients (97.4\%). In three cases, it was associated with gentamicin. Cephalothin was prescribed in three cases and amicacin or cefoxitin with gentamicin was used in only one patient for each regimen.

According to - Table 3, among the antibiotics tested, the highest bacterial resistance index involve ampicillin (52\%) and first-generation cephalosporin (36.2\%). Ceftriaxone had

Table 2 Description of the bacteria isolated in the urine culture of pregnant women with pyelonephritis treated in the UH / UFSC, during the years 2010 to $2016(n=171)$

\begin{tabular}{|l|l|}
\hline Bacteria isolated in urine culture & $\mathbf{n ~ ( \% )}$ \\
\hline Escherichia coli & $131(76.6)$ \\
\hline Klebsiella pneumoniae & $15(8.7)$ \\
\hline Proteus mirabilis & $7(4.0)$ \\
\hline Streptococus agalactiae & $5(2.6)$ \\
\hline Enterococcus faecalis & $3(1.7)$ \\
\hline Enterobacter aerogenes & $2(1.1)$ \\
\hline Staphylococcus epidermidis & $2(1.1)$ \\
\hline Pseudomonas aeruginosa & $2(1.1)$ \\
\hline Others* & $4(2.3)$ \\
\hline Total & $171(100.0)$ \\
\hline
\end{tabular}

*Citrobacter sp (1); Staphylococcus saprophyticus (1); Streptococcus pneumonia (1); Enterococcus faecium (1). 
Table 3 Breakdown of the resistant/intermediate results in the antibiograms performed on the pregnant women who had pyelonephritis during pregnancy, attended at UH / UFSC, during the years 2010 to 2016

\begin{tabular}{|c|c|c|c|c|c|c|c|c|c|c|}
\hline & $\begin{array}{l}\text { EC } \\
(n=131) \\
n(\%)\end{array}$ & $\begin{array}{l}\text { KP } \\
(n=15) \\
n(\%)\end{array}$ & $\begin{array}{l}\text { PM } \\
(n=7) \\
n(\%)\end{array}$ & $\begin{array}{l}\text { SA } \\
(n=5) \\
n(\%)\end{array}$ & $\begin{array}{l}\mathrm{EF} \\
(n=3) \\
n(\%)\end{array}$ & $\begin{array}{l}\mathrm{EA} \\
(n=2) \\
\mathrm{n}(\%)\end{array}$ & $\begin{array}{l}\text { SE } \\
(n=2) \\
n(\%)\end{array}$ & $\begin{array}{l}\mathrm{PA} \\
(n=2) \\
\mathrm{n}(\%)\end{array}$ & $\begin{array}{l}\text { Others } \\
(n=4) \\
n(\%)\end{array}$ & $\begin{array}{l}\text { Total } \\
(n=171) \\
n(\%)\end{array}$ \\
\hline Nalidixic Acid & $\begin{array}{l}18 \\
(13.7)\end{array}$ & $\begin{array}{l}1 \\
(6.7)\end{array}$ & 0 & $\begin{array}{l}5 \\
(100.0)\end{array}$ & $\begin{array}{l}1 \\
(33.3)\end{array}$ & 0 & 0 & 0 & $\begin{array}{l}1 \\
(25.0)\end{array}$ & $\begin{array}{l}26 \\
(15.2)\end{array}$ \\
\hline $\begin{array}{l}\text { Amoxicillin + } \\
\text { Clavulanate }\end{array}$ & $\begin{array}{l}2 \\
(1.5)\end{array}$ & $\begin{array}{l}4 \\
(26.7)\end{array}$ & 0 & 0 & $\begin{array}{l}1 \\
(33.3)\end{array}$ & 0 & 0 & 0 & 0 & $\begin{array}{l}7 \\
(4.0)\end{array}$ \\
\hline Ampicillin & $\begin{array}{l}66 \\
(50.4)\end{array}$ & $\begin{array}{l}12 \\
(80.0)\end{array}$ & $\begin{array}{l}3 \\
(42.9)\end{array}$ & 0 & $\begin{array}{l}2 \\
(66.7)\end{array}$ & $\begin{array}{l}2 \\
(100.0)\end{array}$ & 0 & $\begin{array}{l}2 \\
(100.0)\end{array}$ & $\begin{array}{l}2 \\
(50.0)\end{array}$ & $\begin{array}{l}89 \\
(52.0)\end{array}$ \\
\hline Ceftriaxone & $\begin{array}{l}4 \\
(3.0)\end{array}$ & $\begin{array}{l}1 \\
(6.7)\end{array}$ & 0 & 0 & $\begin{array}{l}1 \\
(33.3)\end{array}$ & 0 & 0 & 0 & 0 & $\begin{array}{l}6 \\
(3.5)\end{array}$ \\
\hline Cephalothin & $\begin{array}{l}45 \\
(34.3)\end{array}$ & $\begin{array}{l}7 \\
(46.7)\end{array}$ & $\begin{array}{l}1 \\
(14.3)\end{array}$ & 0 & $\begin{array}{l}2 \\
(66.7)\end{array}$ & $\begin{array}{l}2 \\
(100.0)\end{array}$ & $\begin{array}{l}1 \\
(50.0)\end{array}$ & $\begin{array}{l}2 \\
(100.0)\end{array}$ & $\begin{array}{l}2 \\
(50.0)\end{array}$ & $\begin{array}{l}62 \\
(36.2)\end{array}$ \\
\hline Ceftazidime & $\begin{array}{l}6 \\
(4.6)\end{array}$ & 0 & 0 & 0 & $\begin{array}{l}1 \\
(33.3)\end{array}$ & 0 & 0 & 0 & 0 & $\begin{array}{l}7 \\
(4.0)\end{array}$ \\
\hline Ciprofloxacin & $\begin{array}{l}4 \\
(3.0)\end{array}$ & $\begin{array}{l}2 \\
(13.3)\end{array}$ & 0 & 0 & $\begin{array}{l}0 \\
(0.0)\end{array}$ & 0 & 0 & 0 & 0 & $\begin{array}{l}6 \\
(3.5)\end{array}$ \\
\hline Gentamicin & $\begin{array}{l}4 \\
(3.0)\end{array}$ & $\begin{array}{l}4 \\
(26.7)\end{array}$ & $\begin{array}{l}2 \\
(28.6)\end{array}$ & $\begin{array}{l}5 \\
(100.0)\end{array}$ & $\begin{array}{l}1 \\
(33.3)\end{array}$ & 0 & 0 & 0 & $\begin{array}{l}2 \\
(50.0)\end{array}$ & $\begin{array}{l}18 \\
(10.5)\end{array}$ \\
\hline Nitrofurantoin & $\begin{array}{l}3 \\
(2.3)\end{array}$ & $\begin{array}{l}5 \\
(33.3)\end{array}$ & $\begin{array}{l}5 \\
(71.4)\end{array}$ & 0 & $\begin{array}{l}0 \\
(0.0)\end{array}$ & $\begin{array}{l}2 \\
(100.0)\end{array}$ & 0 & $\begin{array}{l}2 \\
(100.0)\end{array}$ & 0 & $\begin{array}{l}17 \\
(9.9)\end{array}$ \\
\hline $\begin{array}{l}\text { Sulfamethoxazole + } \\
\text { Trimethoprim }\end{array}$ & $\begin{array}{l}14 \\
(10.7)\end{array}$ & $\begin{array}{l}2 \\
(13.3)\end{array}$ & $\begin{array}{l}2 \\
(28.6)\end{array}$ & $\begin{array}{l}2 \\
(40.0)\end{array}$ & $\begin{array}{l}1 \\
(33.3)\end{array}$ & 0 & 0 & $\begin{array}{l}1 \\
(50.0)\end{array}$ & $\begin{array}{l}1 \\
(25.0)\end{array}$ & $\begin{array}{l}23 \\
(13.4)\end{array}$ \\
\hline
\end{tabular}

Abbreviations: EA, Enterobacter aerogenes; EC, Escherichia coli; EF, Enterococcus faecalis; KP, Klebsiella pneumoniae; PA, Pseudomonas aeruginosa; PM, Proteus mirabilis; SA, Streptococcus agalactiae; SE, Staphylococcus epidermidis.

the lowest bacterial resistance index, evidenced in only 6 patients. A result similar to the one of the quinolone studied, which obtained only $3.5 \%$ of resistance in total and to that of ceftazidime (4\%) (-Table 3 ).

The mean birth weight of the children of patients with pyelonephritis was 3,211.3 $\mathrm{g}$ with a standard deviation (SD) of 282.3, similar to the average birth weight of 3,218.3 g (SD 432.1) $(p=0.781)$. For pregnant women who had pyelonephritis, the mean GA for delivery was 39.1 weeks (SD 1.2), while the mean GA for the other women was 38.9 weeks (SD 1.6) ( $p=0.617$ ).

According to the perinatal results shown in - Table 4, patients diagnosed with pyelonephritis had a greater risk of very premature delivery (3.3\%) compared with only $1.2 \%$ of patients with no prior history of the infection $(p<0.023)$.

\section{Discussion}

There is a consensus in scientific studies that pyelonephritis in pregnancy causes an increase in maternal and fetal morbidity, as well as an increase in the hospitalization of pregnant women. Among the complications related to pyelonephritis, anemia, septicemia with consequent need for ICU, fever and fetal changes, such as low birth weight and premature delivery, are prominent. ${ }^{10,13}$

In this study, the collection performed through the available database presents some limitations, since the information regarding the clinical history of the patients studied were written by different professionals.
A prevalence of $1.97 \%$ of pregnant women with pyelonephritis was found during this study, a result that is in agreement with other studies such as the one by Hill et al, ${ }^{9}$ in which a value of $1.4 \%$ was found.

Most of the diagnosed pregnant women were in the second and third trimester of gestation (88.9\%), which is in agreement with findings by Dawkins et al. ${ }^{2}$ It is believed that this finding correlates with the peak period of urinary stasis and immunological changes in the urinary tract due to hormonal influence. ${ }^{9}$

Regarding laboratory findings, anemia is one of the most common complications of pyelonephritis, present in $\sim 25 \%$ of patients, a finding similar to the one in the present study (21.8\%). ${ }^{9}$ Despite the difficulty of identifying the type of anemia, it is known that hemolytic anemia is more common in pregnant women with pyelonephritis due to the activity of bacterial endotoxins and consequent erythrocyte destruction. ${ }^{14}$

Dawkins et al, ${ }^{2}$ in a study conducted in Jamaica, showed that $81.4 \%$ of the women had leukocyturia, which was also the most frequent alteration in the present study. Although the basic urine test can translate a possible UTI, this test will actually show signs of inflammation in the urinary tract, not necessarily an infection. ${ }^{15}$ Due to its low specificity, other conditions like pelvic inflammatory disease, glomerulonephritis and sexually transmitted diseases can also have a positive white blood cell count in the urine. ${ }^{16}$

A group of 17 patients (8.8\%) who were diagnosed with pyelonephritis required a longer than usual hospital stay, and $7.2 \%$ of them needed ICU care. They were patients who had some 
Table 4 Comparison of perinatal characteristics among pregnant women with a history of pyelonephritis $(n=192)$ and those without prior history ( $n=6,010$ ) who had their delivery in HU / UFSC between 2010 and 2016

\begin{tabular}{|c|c|c|c|c|c|}
\hline \multirow[t]{2}{*}{ Variables } & \multirow{2}{*}{$\begin{array}{l}\mathrm{PN} \\
\mathrm{n}(\%)\end{array}$} & \multirow{2}{*}{$\begin{array}{l}\text { Others } \\
\mathrm{n}(\%)\end{array}$} & \multirow{2}{*}{$\begin{array}{l}\text { Gross OR } \\
\text { (Cl 95\%) }\end{array}$} & \multirow{2}{*}{$\begin{array}{l}\text { Adjusted OR } \\
\text { (Cl 95\%) }\end{array}$} & \multirow[t]{2}{*}{$p$} \\
\hline & & & & & \\
\hline Premature delivery (GA < 37 weeks) & $\begin{array}{l}14 \\
(7.3)\end{array}$ & $\begin{array}{l}427 \\
(7.1)\end{array}$ & $\begin{array}{l}1.03 \\
(0.59-1.78)\end{array}$ & $\begin{array}{l}1.22 \\
(0.41-0.62)\end{array}$ & 0.921 \\
\hline Very premature delivery (GA $<32$ weeks) & $\begin{array}{l}6 \\
(3.3)\end{array}$ & $\begin{array}{l}72 \\
(1.2)\end{array}$ & $\begin{array}{l}2.66 \\
(1.14-6.19)\end{array}$ & $\begin{array}{l}2.50 \\
(1.11-9.88)\end{array}$ & 0.023 \\
\hline Cesarean & $\begin{array}{l}66 \\
(34.4)\end{array}$ & $\begin{array}{l}1917 \\
(31.9)\end{array}$ & $\begin{array}{l}1.12 \\
(0.82-1.51)\end{array}$ & $\begin{array}{l}1.34 \\
(0.72-1.62)\end{array}$ & 0.468 \\
\hline$\uparrow$ Bleeding & $\begin{array}{l}8 \\
(4.1)\end{array}$ & $\begin{array}{l}192 \\
(3.2)\end{array}$ & $\begin{array}{l}1.31 \\
(0.64-7.71)\end{array}$ & $\begin{array}{l}1.39 \\
(0.55-6.79)\end{array}$ & 0.454 \\
\hline Birth Weight $<2.500 \mathrm{~g}$ & $\begin{array}{l}13 \\
(6.7)\end{array}$ & $\begin{array}{l}433 \\
(7.2)\end{array}$ & $\begin{array}{l}0.93 \\
(0.52-1.66)\end{array}$ & $\begin{array}{l}1.0 \\
(0.42-2.16)\end{array}$ & 0.819 \\
\hline APGAR $<71^{\circ} \mathrm{min}$ & $\begin{array}{l}10 \\
(5.2)\end{array}$ & $\begin{array}{l}252 \\
(4.2)\end{array}$ & $\begin{array}{l}1.25 \\
(0.65-2.40)\end{array}$ & $\begin{array}{l}1.32 \\
(0.54-3.27)\end{array}$ & 0.492 \\
\hline APGAR $<75^{\circ} \mathrm{min}$ & $\begin{array}{l}2 \\
(1.0)\end{array}$ & $\begin{array}{l}48 \\
(0.8)\end{array}$ & $\begin{array}{l}1.31 \\
(0.31-5.42)\end{array}$ & $\begin{array}{l}1.28 \\
(0.45-4.82)\end{array}$ & 0.712 \\
\hline Preeclampsia & $\begin{array}{l}10 \\
(5.1)\end{array}$ & $\begin{array}{l}270 \\
(4.5)\end{array}$ & $\begin{array}{l}1.17 \\
(0.61-2.23)\end{array}$ & $\begin{array}{l}1.25 \\
(0.71-3.6)\end{array}$ & 0.638 \\
\hline
\end{tabular}

Abbreviations: APGAR, appearance, pulse, grimace, activity and respiration; $\mathrm{Cl}$, confidence interval; $\mathrm{GA}$, gestational age; OR, odds ratio; PN, pyelonephritis.

type of complication and, consequently, were in need of care in the ICU and/or surgical procedure. More serious complications may occur due to endothelial damage in capillaries, caused by an immune response to endotoxins from gram negative bacteria, resulting in an increased risk of septic shock, respiratory failure, and disseminated intravascular coagulation. ${ }^{5}$

All the authors indicate Escherichia coli (E. Coli) as the main microorganism involved in the diagnosis of pyelonephritis, which coincides with the results found in (76.6\%) the urine cultures analyzed at the hospital. ${ }^{2,9,10,17,18}$ After E. coli, the most common microorganisms were Klebsiella pneumoniae $(8.7 \%)$ and Proteus mirabilis (4.0\%). There was no pathogen identification in $\sim 11 \%$ of the patients, possibly due to previous antibiotic therapy or method limitations.

The antibiotic used as the first choice was ceftriaxone, which showed low bacterial resistance (3.5\%). First-generation ampicillin and cephalosporin (cephalothin) were the antibiotics that showed the highest bacterial resistance, 52\% and $36.2 \%$ of the cases, respectively. Thus, we recommend avoiding the use of these routine antibiotics. In contrast, Artero et $\mathrm{al}^{10}$ used amoxicillin with clavulanate and cephalosporins as the first choice, finding a resistance of $14 \%$ with amoxicillin and clavulanate in E. coli infections. Studies have found similar results regarding bacterial resistance to ampicillin (49\%) and a higher rate of antibiotic therapy replacement. ${ }^{10,19}$ According to the International Guideline of the Society of Infectious Diseases of America and the European Society of Microbiology and Infectious Diseases, for the treatment of pyelonephritis, ampicillin, as well as amoxicillin, should not be routinely used for empirical treatment because of the great resistance to both antibiotics. ${ }^{20}$

In this study, there was no statistically significant difference in overall prematurity when compared with patients without the diagnosis of pyelonephritis during pregnancy.
Nonetheless, a study conducted in the United States found different results, showing that patients with pyelonephritis are more likely to have preterm birth when compared with non-diagnosed patients (10.3\% versus $7.9 \%$, respectively). ${ }^{19}$ In the subgroup of very premature ( $<32$ weeks), however, the history of pyelonephritis increased the chance of prematurity by more than $50 \%$. The study by Wing et $\mathrm{al}^{21}$ also suggests that patients treated for pyelonephritis at the end of gestation have a higher incidence of preterm birth.

The incidence of low birth weight of $6.7 \%$ is relatively low when compared with other studies such as that of Sharma et $a,^{22}$ who found a value of $13.82 \%$. This difference may be related to improved follow-up after the treatment of pyelonephritis, but also to the characteristics of the population studied.

Regarding patients with pyelonephritis, when analyzing the incidence rate of cesarean section, the number of patients with increased bleeding postpartum, and patients with preeclampsia, no significant differences were found when compared with the values of patients who did not have the diagnosis of the infection. A study in the USA conducted by Dotters-Katz et al ${ }^{13}$ showed clinical and statistical difference in which pregnant women with pyelonephritis had lower rates of cesarean section, postpartum hemorrhage and preeclampsia compared with patients without the prognosis $(p<0.0001)$.

\section{Conclusion}

In conclusion, the study showed an increased risk for very premature delivery ( $<32$ weeks) in patients who had pyelonephritis during pregnancy. This research also indicates that the use of ceftriaxone for the treatment of pyelonephritis during pregnancy is an adequate choice due to low bacterial resistance. These findings may be useful for updating protocols and routines. 


\section{Contributions}

All the authors participated in the selection of the theme, gathering of references and the study design. Mariane de Mello Rossini performed data collection, data analysis and transcription of the results. Djulie Anne de Lemos Zanatta performed data analysis, interpretation of the results and wrote the article. Alberto Trapani worked as the advisor of the team, collected data, guided the other authors through the interpretation of the data and performed a critical review of the intellectual content. All authors read and reviewed the article and gave the final approval of the version to be published.

\section{Conflicts of Interest}

There was no conflict of interest in this study.

\section{References}

1 Wing DA, Fassett MJ, Getahun D. Acute pyelonephritis in pregnancy: an 18-year retrospective analysis. Am J Obstet Gynecol 2014;210(03):219.e1-219.e6 Doi: 10.1016/j.ajog.2013.10.006

2 Dawkins JC, Fletcher HM, Rattray CA, Reid M, Gordon-Strachan G. Acute pyelonephritis in pregnancy: a retrospective descriptive hospital based-study. ISRN Obstet Gynecol 2012;2012:519321

3 Duff P. Pyelonephritis in pregnancy. Clin Obstet Gynecol 1984;27 (01):17-31

4 Jain V, Das V, Agarwal A, Pandey A. Asymptomatic bacteriuria \& obstetric outcome following treatment in early versus late pregnancy in north Indian women. Indian J Med Res 2013;137(04):753-758

5 Jolley JA, Wing DA. Pyelonephritis in pregnancy: an update on treatment options for optimal outcomes. Drugs 2010;70(13): 1643-1655

6 Figueiró-Filho EA, Bispo AMB, Celestino FG, Maia MZ, Vasconcelos MM. Infecção do trato urinário na gravidez: aspectos atuais. Femina 2009;37:165-171

7 Cunningham FG, Leveno KJ, Bloom SL, et al. Obstetrícia de Williams. 24a ed. Porto Alegre: AMGH; 2016

8 Ovalle A, Levancini M. Urinary tract infections in pregnancy. Curr Opin Urol 2001;11(01):55-59

9 Hill JB, Sheffield JS, McIntire DD, Wendel GD Jr. Acute pyelonephritis in pregnancy. Obstet Gynecol 2005;105(01):18-23
10 Artero A, Alberola J, Eiros JM, Nogueira JM, Cano A. Pyelonephritis in pregnancy. How adequate is empirical treatment? Rev Esp Quimioter 2013;26(01):30-33

11 Farkash E, Weintraub AY, Sergienko R, Wiznitzer A, Zlotnik A, Sheiner E. Acute antepartum pyelonephritis in pregnancy: a critical analysis of risk factors and outcomes. Eur J Obstet Gynecol Reprod Biol 2012;162(01):24-27

12 Snyder CC, Barton JR, Habli M, Sibai BM. Severe sepsis and septic shock in pregnancy: indications for delivery and maternal and perinatal outcomes. J Matern Fetal Neonatal Med 2013;26(05):503-506

13 Dotters-Katz SK, Heine RP, Grotegut CA. Medical and infectious complications associated with pyelonephritis among pregnant women at delivery. Infect Dis Obstet Gynecol 2013;2013:124102

14 Schieve LA, Handler A, Hershow R, Persky V, Davis F. Urinary tract infection during pregnancy: its association with maternal morbidity and perinatal outcome. Am J Public Health 1994;84(03): 405-410

15 Duarte G, Marcolin AC, Quintana SM, Cavalli RC. [Urinary tract infection in pregnancy]. Rev Bras Ginecol Obstet 2008;30(02): 93-100

16 Coad S, Friedman B, Geoffrion R. Understanding urinalysis. Expert Rev Obstet Gynecol 2012;7:269-279

17 Dunlow S, Duff P. Prevalence of antibiotic-resistant uropathogens in obstetric patients with acute pyelonephritis. Obstet Gynecol 1990;76(02):241-244

18 McGready R, Wuthiekanun V, Ashley EA, et al. Diagnostic and treatment difficulties of pyelonephritis in pregnancy in resourcelimited settings. Am J Trop Med Hyg 2010;83(06):1322-1329

19 Calegari SS, Konopka CK, Balestrin B, Hoffmann MS, de Souza FS, Resener EV. [Results of two treatment regimens for pyelonephritis during pregnancy and correlation with pregnancy outcome]. Rev Bras Ginecol Obstet 2012;34(08):369-375

20 Gupta K, Hooton TM, Naber KG, et al; Infectious Diseases Society of America; European Society for Microbiology and Infectious Diseases. International clinical practice guidelines for the treatment of acute uncomplicated cystitis and pyelonephritis in women: A 2010 update by the Infectious Diseases Society of America and the European Society for Microbiology and Infectious Diseases. Clin Infect Dis 2011;52(05):e103-e120

21 Wing DA, Hendershott CM, Debuque L, Millar LK. Outpatient treatment of acute pyelonephritis in pregnancy after 24 weeks. Obstet Gynecol 1999;94(5 Pt 1):683-688

22 Sharma P, Thapa L. Acute pyelonephritis in pregnancy: a retrospective study. Aust N Z J Obstet Gynaecol 2007;47(04):313-315 